\title{
Churchill's Island and 'Bush's Island'
}

\author{
By Robert Christopher Nellis \\ Spring 2006 Issue of KINEMA

\section{CHURCHILL'S ISLAND AND REFLECTIONS UPON 'BUSH'S ISLAND' AND THE 'WAR ON TERROR'}

In those fateful autumn days of 1940 when none knew what terror the skies might hold, there appeared from end to end of Britain the strangest fighting force the world has ever seen, an army of citizens, self-organized, self-disciplined. Their armament? Hoses, stirrup pumps, sand bags, brooms, and buckets. Their purpose, to save their town, their city, their community from the fate of Rotterdam and Warsaw. (Legg, 1941)

These words are part of the narration from a classic Wartime documentary film, a propaganda film if you will, called Churchill's Island (Legg, 1941). It is not a British film as one may imagine, but is, in fact, an early effort of the National Film Board of Canada, an example of one of its Wartime 'patriotic' (National Film Board of Canada, 2003) films. Churchill's Island was successful and well received at the time. Such early films as this are an often overlooked yet rich resource within Canada's cultural heritage, harkening to the days the NFB sent its own film agents travelling the country and showing the films to all who would view them. In the last number of years, the NFB has closed down many of its regional offices and donated their collections to public libraries. As those collections age, as the infrastructures of the cultural artifacts deteriorate, the NFB is experimenting with new forms of film delivery. 'CineRoute Public' intends to complement CineRoute University, streaming on-line availability of select classic films for educational use. Even today, despite all the changes in the agency, NFB films remain a valuable media resource.

With the vast array of media available today including the many fine new releases of the NFB, it is easy for the older classic texts to find themselves set aside and eventually forgotten. However, many of these old texts, many of which are recipients of numerous international awards, have much to offer. Indeed, a classic NFB text like Churchill's Island can lend insight into contemporary narratives of conflict, specifically concerning 'Bush's Island' and the Bush administration's 'War on Terror'.

\section{Churchill's Island}

The NFB was founded in 1939 as an amalgamation of a variety of government filmmaking efforts but with a new added emphasis, as NFB founding Commissioner John Grierson described in the Film Act of 1939, to 'make and distribute films designed to help Canadians in all parts of Canada to understand the ways of living and the problems of Canadians in other parts' (Evans, 1991: 17). Grierson is widely credited with inventing the documentary form in Britain in the 1920s and 30s in classic films such as Drifters (1929, director), Song of Ceylon (1934, producer), and Coal Face (1935, producer). His approach to documentary had a strong emphasis on promoting social cohesion with a 'progressive' orientation.

The burgeoning Canadian film agency barely had time to produce its first film, by the same director as Churchill's Island, The Case of Charlie Gordon (Legg \& Badgley, 1939) - an inspiring tale of unemployed youth joining the mainstream workforce through cooperation between government officials in the Labour Department and local employers--before the War broke in September and gave the NFB a new reason for being. During the War years, the NFB, under Grierson's leadership, became the Commonwealth's preeminent producer of War related propaganda. Churchill's Island itself was perhaps Canada's most successful film of the period, winning the Academy Award in 1942 for Best Documentary.

Although the film's title is 'Churchill's Island,' Winston Churchill himself hardly appears. However, the British Prime Minister made a number of speeches before the House of Commons in the time shortly before the film that telegraphed the film's themes concerning the War:

How long it will be, how long it will last depends upon the exertions, which we make on this island. An effort, the like of which has never been seen in our records, is now being made. Work is proceeding night and day. Sundays and weekdays, Capital and Labour have cast aside their 
interests, rights and customs and put everything into the common stock. Already the flow of munitions has leaped forward. (Churchill, 1940)

Indeed, the film treats the unified, cooperative efforts of the British people to work together to protect their island from attack. Social difference and conflict is elided according to the film's representation for the War effort. In a key scene early in the film, the narration proceeds:

Behind the armoured shorelines, 40 million people are at their battle stations. These are Britain's craftsman, the steel puddlers, foundry men, machinists, the men and women who in time of peace made England rich and strong and they it is who have brought about the silent wartime revolution, which demands that nothing shall hinder the fulfilment of the nation's needs. Willingly, they have faced the sacrifices, discomfort, hard rations, long hours, for they know that the hosts across the sea are massing. Every hour is precious. (Legg, 1941)

As the narration rises in passionate crescendo, it is accompanied by the diegetic rumble of machines doing their work, preparing for war, and revealing recently manufactured bombs. The sequence ends with the work-place sign:

The Hour is Striking!

Non-stop attacks in continuous moves are being directed against our Arts and Shipping.

Jump to it... Keep at it!

Hours lost mean lives lost. (1941)

The focus of the film is macro. If individual perspectives are sought or considered at all, such as in brief interviews with soldiers or sailors to get their opinion on 'Gerry,' it is only to support the overall thesis of social cohesion. The film is about the selfless efforts of Britain's industrial workers, volunteer firefighters, and all branches of the Armed Services. Churchill's Island mentions the 'people's' or 'citizen's army' three times. It mentions the personal sacrifices individual Britons make and paints a picture of unwavering strength and readiness for war: 'With every passing hour, this island fortress of Churchill and his people grows more formidable...[within the people, across Britain] lies an inner strength, a stubborn calm, which bomb and fire and steel cannot pierce' (1941). The film ends with a formidable cannon pointing across the Channel toward the continent as narrator Lorne Green chides, 'They stand unconquered as they have stood down a thousand years of history, and still they throw their challenge across those 20 miles of water: Come, if you dare'! (1941).

Although Churchill's Island is an island, surrounded by sea and separated from the continent geographically, it resonates John Donne's famous line from Meditation XVII: 'No man is an island, entire of itself; every man is a piece of the continent, a part of the main' (Donne, 2004). On the continent, the fall of France and the other countries of continental Europe possesses an immediate bearing upon the fortunes and fears of Britain. As the film frames it, the fate of Britain determines both a symbolic and real importance to wider defences against Germany's aggressive expansion. In this sense, Churchill's Island has a somewhat porous character. It experiences both dangers and assistance from without. It receives much support from North America and, indeed, from across the Commonwealth. Assistance comes from Canada and the USA in the form of ships, supplies, and soldiers.

The permeable nature of Churchill's Island affects other nations. Dangers to North American ships running the gauntlet of German U-boats in the Atlantic and beyond directly affect the fortunes of those countries: 'And woe betide the ship attempting to run the gauntlet of the Atlantic alone. Be she Allied, be she neutral, the fact that her course is set towards British shores is enough to seal her fate' (Legg, 1941). A hapless ship is ruthlessly torpedoed and sunk as a shrinking, burning mass in the chill, violent waters of the Atlantic 'All that is left is a group of half-frozen, oil-smeared men, and a lifeboat lurching in the green troughs of the sea' (1941). The film also makes note of the fact that there are 'Sinkings in the south Atlantic, off West Africa and the Cape Verdi Islands, sinkings between the Azores and the Caribbean, between Greenland and Iceland, sinkings in the waters of the western hemisphere - within 700 miles of Canada'! (1941). In this sense, the argument is made that the dangers to Churchill's Island, concomitant with the porous nature of the Island, also function as dangers far beyond her shores. 


\section{Two Themes}

Certain themes in Churchill's Island can illuminate contemporary narratives of conflict. The first is that of social unity against attack from without, and the second is that of the permeable nature of national borders, especially in time of war. These two themes can provide starting points for discussion - first, as they are represented in the early film, Churchill's Island, and second as starting points for discussion of contemporary conflict.

It is important to note, however, that Churchill's Island is not unproblematic, especially with respect to the first theme, that of its representation of social unity. It is important not to over romanticize the film because of the way it removed social difference, inequality, and conflict. Recall the quote from the film:

Behind the armoured shorelines, 40 million people are at their battle stations. These are Britain's craftsman, the steel puddlers, foundry men, machinists, the men and women who in time of peace made England rich and strong and they it is who have brought about the silent wartime revolution, which demands that nothing shall hinder the fulfilment of the nation's needs. Willingly, they have faced the sacrifices, discomfort, hard rations, long hours, for they know that the hosts across the sea are massing. Every hour is precious. (1941)

The statement acknowledges that in times of peace the workers made Britain rich and strong. However, the statement elides class difference and antagonism by not acknowledging the extraction of the surplus value of those workers' labour which, arguably, while it went to make Britain rich and strong, did make did not make all Britons equally rich and strong. Certainly, the owners of Capital benefited more greatly. The statement does not acknowledge Labour differences, such as the history of child Labour; Bloody Sunday, February 13, 1887, in which police attacked Social Democratic Federation members as they tried to meet in Trafalgar Square; the Match Girl Strike of 1888 in which the women who worked at the Bryant \& May match factory protested poor pay, company fines, and poisoning by the use of phosphorus to manufacture the matches; the London dock workers strike of 1889, inspired by the women at Bryant and May; and the 1926 general strike, which culminated in repressive anti labour legislation by the British Government - 1927's Trade Disputes and Trade Union Act, forbidding, among other things, sympathetic strikes and mass picketing.

In addition, the macro perspective, the War's eye view of Churchill's Island, is also blind to other social differences. Certainly, women are mentioned. They served along the same workbench or sometimes in the same citizens' brigades as men, and, in that sense, their representation, such as it is, suggests a kind of equality with their male counterparts. However, it is not controversial to point out that, especially in the early 1940s, the lot of women in Britain was far from equal with men. Thus, their inclusion in the apparently harmonious aggregate of Wartime Britain removes challenges to women under Patriarchy. While women are at least depicted in Churchill's Island, other identification groups do not fare even that well. The film denotes virtually nothing of racial diversity. This is not to suggest that Churchill's Island is completely blind to racial or cultural difference though. The film suggests a curious inversion of the cultural assumptions behind Nazi State Racism, by pointing out apparently essential characteristics of Germans. While the signification steers clear of overt reference to race, or even culture, the film does have a comment about the German high command planning '(W)ith all the patient foresight of their kind' (1941), as we see some frantic, meticulously well-groomed officers examining microfiche with magnifying lenses.

The film does not clarify if by 'their kind' it refers to the German wartime planners or simply Germans in general. However, the lack of clarification certainly feeds into and supports a Commonwealth gaze upon a sort of identifiable, unified German Other as represented by what is analogous to racial or cultural characteristics. Thus, racial difference is irrelevant to British unity but entirely relevant to its relationship to the Other. In addition, the film says nothing of differences in sexual orientation, religion, or other markers of difference. At the level of cultural inscription, Churchill's Island's unity in the face of the Wartime threat 'unifies' out legitimate differences.

These two themes, social unity in times of war and the porous nature of wartime borders, can serve as points to locate the contours of contemporary narratives of conflict in articulations found in the public media record. These points from Churchill's Island can help locate and discern, specifically, a narrative of Bush's 'War on Terror' and then characteristics of 'Bush's Island'. 


\section{'Bush's Island' and the 'War on Terror'}

Statements of social unity in Bush's 'War on Terror' are deployed very differently than in Churchill's Island. After 9-11, Bush explicitly admonished the world, 'Over time it's going to be important for nations to know they will be held accountable for inactivity...You're either with us or against us in the fight against terror' (Bush, 2001, November 6). In Churchill's Island, there was represented a duality: it simply consisted of the Germans and the denizens of Churchill's permeable island, including the supporters from the rest of the Commonwealth and the USA. Dissension upon Churchill's Island was not treated; dissension upon 'Bush's Island' is continuously attempted, and, likewise, continuously attacked by the administration and its supporters. In the lead up to the US invasion of Iraq, much debate occurred. However, dissenting views had to be carefully framed. The suggestion was that if anyone questioned the President or questioned the policies, they were somehow against the troops. Even the most cursory glance at letters to editors or Internet discussion groups will find this view virulently articulated. 'Not supporting the troops' emerged as the cardinal sin, the one thing that no one was allowed to articulate.

Of course, this issue has a history in American military policy. It is widely considered that media accounts of the war in Vietnam helped to fuel antiwar sentiment and thereby undermine public opinion and the political will to carry out the war. This is a lesson understood well by the US military, as the media has not enjoyed that kind of access since. Even in World War II, journalists had to have their stories reviewed by censors, and in some cases, stories were not allowed to run, but the stories still existed, and were there to form the historical record. In American conflicts since Vietnam, media access has been tightly controlled and historic records were not given the chance to emerge. Thus, a very limited picture of American wartime activities ensued.

Today, one is not 'permitted' to question the troops - by questioning the policies or, indeed, even by questioning the troops, one somehow condemns them. However, those whom the soldiers condemn in their campaigns, which, of course, are beyond reproach, are not considered. In the fallout from the American 'interrogation' activities at Abu Ghraib prison, the incriminating pictures, of course, did not come from the media, but from US soldiers themselves. Politicians argued to have publication of the photos suppressed, citing that it would stir up more hatred toward Americans in the region. Others argued that the authorities should release the pictures, but not in the interests of full disclosure or honesty and reconciliation, rather, for the politically expedient purpose of avoiding future politically inconvenient episodes as they surface clandestinely. Others argued in the same vein that it is inevitable other pictures will emerge, so the authorities should release them now (Henry, et al, 2004). Echoes of Vietnam cry out.

Indeed, in the fallout of Abu Ghraib, ideology reveals itself. All of the outrages, the torturing of the Iraqi detainees, as well as all of the military mishaps since the beginning of the Bush administration, beginning with the surfacing submarine that hit the Japanese ship, killing 9 civilians including 4 high school students ('US Sub,' 2001), to the deaths of Canadian servicemen April 18, 2002 in Afghanistan ('Canada Launches,' 2002), to the massacre at an Afghan wedding party ("Scores Killed', 2002), to the civilians killed by American bombs and military activities in Iraq ('Death In,' 2004), it is all seen as an aberration of a 'sanitized,' 'managerial' conception of the War.

The line from Shakespeare's Julius Caesar by Marc Antony, 'Cry 'havoc,' and let slip the dogs of war' (2001: 3.1.275) seems lost on Bush and his advisers Cheney, Wolfowitz, Perle, etc., that when you unleash the dogs war, when you let the genie out of the bottle, the only thing you can be sure that will happen is tragedy. It is an illusion of administrative, bureaucratic, military 'management' that such things can be avoided. These are the sure effects of war. If they were not, then surely the commanders would not need to control so strictly access of the media. Regardless, even with such clampdown access, pictures such as those from Abu Ghraib still make it through the cracks.

In the days leading up to the American invasion of Iraq, people filled streets all over the world against the unilateralism of the action ('Millions Say,' 2003). Bush chided the UN: 'Will the United Nations serve the purpose of its founding or will it be irrelevant'? ('Bush's UN,' 2002), threatening unilateral action unless Iraq quit its weapons programs. November 8, 2002, the UN issued Resolution 1441 authorizing inspections ('UN Adopts,' 2002). However, impatient with inspections, Bush gave Saddam 48 hours to leave Iraq or face invasion ('Bush Ultimatum,' 2003). Inevitably, the American-led coalition attacked, March 20, 2003: 
'Explosions are heard in Baghdad, 90 minutes after President Bush's deadline for Saddam Hussein to go into exile or face war expires' ('Timeline: Steps,' 2003). Dissent did not matter. The only unity Bush apparently needed was the unity of his own rationale and any other of the 'coalition of the willing' that would come along. Indeed, unity on 'Bush's Island' was very different from unity on Churchill's Island. It could not contain the disunity, whether in public debate, through the media, international opinion, or the illusions of a bureaucratic, managerial style of warfare. 'Bush's Island"s unity, like Churchill's Island's borders, ironically, is porous.

However, the borders of 'Bush's Island,' both the geographical borders as well as the imaginary borders, like those of Churchill's Island, are permeable as well, both porous and dispersed. One point that the Bush administration has been careful to point out, especially in the early days after 9-11, was that the 'War on Terror' is a new kind of war ('Rice: Terrorism,' 2001). There is no clearly defined front where each side meets, aware of the presence and intentions of the other. Rather, the front line on the 'War on Terror' can be anywhere. It can be, indeed, in the heart of New York City, Kenya ('Statement Says,' 2003), Saudi Arabia and Morocco ('Video Claims,' 2003), Madrid ('Madrid Bombing,' 2004), Afghanistan (Garrett \& King, 2001) or, as the Bush administration asserts, Iraq ('Bush: Iraq,' 2003).

There is also a difference, nevertheless, in the permeable nature of Bush's borders with Churchill's borders in the nations' relationship with neighbours and 'allies'. There is a fundamentally different logic at play. In Churchill's Island, most of continental Europe had fallen to the Axis powers, and Britain was the lone nation remaining in the area to fall to the German aggression. In the case of 'Bush's Island' and notwithstanding the strong claims:

The events in New York and Washington on September 11, 2001 were not just an attack on America and Americans. The World Trade Center bombing claimed victims from some 80 nations - from our close neighbors Canada and Mexico to countries as far away as Australia and Zimbabwe, and large numbers from Britain, India, and Pakistan. For many countries, including ours, this attack claimed the lives of the largest numbers of their citizens in a terrorist incident. These terrorist attacks may have been conceived as a blow against America but in reality they were attacks against all civilized people, (Taylor, 2001)

The object of the 9-11 attacks were not the world, the non-Islamic world, the non-Islamic-fundamentalist world, or 'Western civilization'. It was the United States. The attacks were not against Canada and they were not against Mexico, the US's neighbours. They were against the United States. In the attacks subsequent to 9-11 and Bush's 'War on Terror,' it is true that other nations have been targeted. However, they were targeted partly because of geographical and security convenience and because of the targets' affinity with Bush's 'War on Terror'. In contrast, Britain in World War II was the lone holdout from conquest among its neighbours. The rhetoric of the 'War on Terror' would have all believe that a similar if reversed logic is at play: if the United States falls then who will protect them, who will protect 'civilization'? In a sense, the context of Churchill's Island was that it was the lone, tenuous front line of defence in what was properly the world's war, but, in Bush's 'War on Terror,' the logic inversely suggests that the world is the tenuous front line of defence in this, what is properly, the US's war.

\section{Narratives}

From the two themes of Churchill's Island, social unity in times of war and the porous nature of wartime borders, a viewer can discern a certain narrative, at least in terms of its broad contours, of Bush's 'War on Terror'. Bush frames the war in terms of evil and accountability:

We're going to find those evildoers, those barbaric people who attacked our country, and we're going to hold them accountable... We're going to hold the people who house them accountable. The people who think they can provide them safe havens will be held accountable. The people who feed them will be held accountable. (Bush, 2001, September 17)

The war is against the 'evildoers' and those who help them. If they are the evildoers, then surely Bush and his side of the war fight with the comfort of transcendent righteousness. There is little room here for grey areas. As Bush himself phrased it, 'You're either with us or against us in the fight against terror' (Bush, 2001, November 6). In Bush's binary, there are either evildoers or warriors of right. The professed 
narrative of Bush's 'War on Terror,' then, is starkly dualistic. This character is certainly inconsistent with the admitted front-less aspect of the war. With a clearly demarcated front line of battle, that type of geographical imaginary lends itself to a bifurcation, at least of friend and foe. However, the admittedly cast forth nature of the front line in the 'War of Terror' complicates the moral duplex that drives it.

The evildoers are no longer 'over there,' (1917) as George M. Cohan's WWI song proclaims. They are no longer in their U-boats in the Atlantic or across the English Channel with guns pointed 'our' way. In the complicated geography of Bush's moral binary, the evil doers are among us. The Bush administration's practice of issuing terror alerts further problematizes the border issue. Even in the times of Churchill's Island, citizens could expect to hear an air raid signal if planes were spotted approaching the island from the mainland. However, in the era of Bush's 'War on Terror,' there are no clear signals of threats such clear threats as German bombers approaching. Intelligence is secret, and, as revealed in the fallout from not discovering weapons of mass destruction upon the US's invasion of Iraq, of questionable, if politically charged value. The Government simply assesses intelligence and issues an order. Moreover, alerts need not demonstrate specificity in terms of the nature of the threat, the target, nor even the time frame. In May 2004, Attorney General John Ashcroft issued an alert for the entire summer (Arena, et al, 2004). The summer correlated with the run-up to the fall election, in which the Bush administration was falling in the polls as the saga of the Iraqi war became more brutal and the folly of the invasion more obvious.

In the election campaign, the administration strategically positioned itself as the provider of security. Certainly, there is at least a convenient political correlation that Ashcroft's alert, lacking any specificity, can be issued at such a time that the administration may greatly wish to reassert its role as the authoritative provider of safety and security. Ashcroft alluded to the case of the Spanish elections after the Madrid bombings, 'The Madrid railway bombings were perceived by Osama bin Laden and Al Qaeda to have advanced their cause.

Al Qaeda may perceive that a large-scale attack in the United States this summer or fall would lead to similar consequences' ('Attorney General,' 2004). Train stations in Madrid were bombed and many people killed and injured. The story went that the bombing was in retaliation for Spain's participation in Bush's coalition of the willing in the invasion of Iraq. Consequently, in a near concomitant election, the Spanish voters ousted the Bush-supporting regime and installed a socialist government, which promptly withdrew Spanish forces from Iraq (Noah, 2004). Ashcroft explicitly invoked these events and seemed to frame political continuity (reelecting Bush) as a patriotic act against terror. In other words, to vote against President Bush would be to play into the hands of the terrorists, the evildoers.

Such political machinations allude to the divisive nature of the political landscape in America. After the US Supreme Court reversed the earlier Florida Supreme Court decision allowing certain manual recounts and de facto handed Bush the presidency, Bush had become, in many respects, the visible face of America all over the world. Politically, the country is very divided - obviously, the 2,000 election was the closest in US history. Bush's 'War on Terror' divides America against the evildoers in a propagated nature in which the front line can be anywhere in the world, including within the borders of the United States. As a matter of Bush's political survival, the Presidential election in November 2004 functions as a key strategic moment in both the execution of the war and the political fortunes of the Bush administration. In this sense, the 'War on Terror' and the Bush administration itself become synonymous. The 'War on Terror,' in this light, comes to be seen not as a war of America against terror or indeed terror against America, but in its ongoing manifestation, of terror against the Bush administration. The war itself, which early on had served as Bush's most important political asset, can come to function as the wedge, which will divide America against Bush.

Indeed, 'Bush's Island' is fraught with contradiction. Where the text of Churchill's Island, admittedly with some problems, presented a surface picture of integrated macro unity, commonality of purpose, and a sense of national urgency, a reading of 'Bush's Island' can discern a certain dominant narrative along the lines: Americans are behind their President; their President does what is right, and the entire world is behind America. This implied unity is against the threat of evildoers, and, therefore, the war and the unity of purpose are just. However, ruptures and fissures abound in the narrative. Firstly, America is deeply divided on the issue of the President, the President's legitimacy stemming back from the 13 December 2,001 supreme court edict, the justice of the war, and the success of the war. As the war drags on and costs become clearer in 
terms of lives and reputation, many Americans waiver in their support ('Poll Finds,' 2004). The a posteriori difficulty with the war obviously is not the same as 'principled' opposition to the war. Here, in the later dips in support, it seems support for the war as long as it is going to be easy changes as difficulty sets in. As the war becomes increasingly difficult, much support fades.

Such contradictions go hand in hand with the splintered nature of borders in the 'War on Terror'. The front line can be anywhere across the globe, or anywhere within the United States. This affects the experience of the conflict and affects the unity of purpose. Deep debates of discursive regulation emerge. In the media, any criticism of the war or policies need to be carefully framed so as not to criticize the troops. The troops become the embodiment or the symbol or signifier for the war itself. The troops become a hegemonic ground zero. In this sense, the dispersed front line, especially as it emerges inside the United States, takes on the character of ideological clash, which is played out on the TV screens every night and in the coffee shops across the country, as the hegemonic support for the war is continually reinserted and re-inscribed even in critique. Thus, the troops themselves, the institution of war, seem safe from critique in the general sense. The ideological constraints serve to keep that terrain partitioned off. Actions of the institution, in the particular instance, of Bush's 'War on Terror' and how they will affect the fortunes of the Bush administration may indeed incur a different fate - Bush may find himself exposed and unprotected in the November 2 election.

\section{Conclusion}

The classic NFB film Churchill's Island, which is also a classic of World War II Allied propaganda, can offer contemporary audiences a lens through which to view and discern the narrative contours of 'Bush's Island' and Bush's 'War on Terror'. The film presents two interesting themes. First, that of remarkable wartime unity, harmony (at least on the side of the Britons) and a singularity of purpose in defending the nation from attack from without. Second, the film reveals a kind of permeable nature to the wartime borders of Britain, in that the hands of help from abroad, specifically from the Commonwealth, Canada, and America reached far across the Atlantic and spend their fingers of support into and underneath Britain. The British erected a fortification against German attack, but it was welcoming to support from friends. These themes reveal certain differences in 'Bush's Island'. First, unity in 'Bush's Island' is far from secure (articulations of unity in Churchill's Island were problematic, admittedly), but statements of unity upon 'Bush's Island' collapse under the buckling disunity that Bush's 'us-versus-them' execution of his 'War on Terror' engenders. Second, it is a professed characteristic of the 'War on Terror' that old ideas of border, such as the circumference of the British isles, are cast asunder as the front line can be anywhere in the world. Attacks on Americans or their allies can take place anywhere, even within the United States. Moreover, the theme of scattered borders lends further to the disunity of the first theme. In fact, a pervasive sense of fear and mistrust in tandem with severe ideological regulation ('You're either with us or against us' (Bush, 2001, November 6) - 'If you're against the war, you must be against the troops') further contribute to the disunity of 'Bush's Island'.

In the 2004 Presidential election, Americans cast their vote in keeping very much with Bush's strict tendency toward bifold oppositions and alienating either/or choices. Although the Bush victory proved decisive, the country remained divided after an effective referendum on the man - and, by extension, on his 'War on Terror'. Iraq figured centrally, and the election confirmed the troubling borders of 'Bush's Island'. To return to Donne's words that 'No man is an island, entire of itself; every man is a piece of the continent, a part of the main' (Donne, 2004), the inhabitants of the Island chose to remain an Island. The electoral decision kept America increasingly alienated from others and itself, rather than joined to the main. According to the trajectory logic of the 'Bush's Island' narrative, the election reasserted America as The Continent, The Main, and 'scattered' the world asunder as islands of 'consequence' only so long as they support Bush's vision.

\section{References}

Arena, K. et al. (2004, May 26) Ashcroft: Al Qaeda intends to attack US CNN.com. http://www.cnn.com/2004/US/05/26/terror.threat/index.html. June 4, 2004.

Attorney General John Ashcroft... (2004, May 27) CBS News.com. Video file. http://www.cbsnews.com/stories/2004/05/27/terror/main619874.shtml. June 7, 2004. 
Bush, G. (2001, September 17) Bush: bin Laden 'prime suspect'. CNN.com.

http://www.cnn.com/2001/US/09/17/bush.powell.terrorism/index.html. June 4, 2004.

Bush, G. (2001, November 6) Bush says its time for action. CNN.com.

http://www.cnn.com/2001/US/11/06/ret.bush.coalition/index.html. June 3, 2004.

Bush: Iraq, al Qaeda linked. (2003, January 30) CNN.com. June 4, 2004.

http://www.cnn.com/2003/ALLPOLITICS/01/29/sprj.irq.bush.iraq/index.html.

Bush's UN speech: Full text. (2002, September 13) BBC News.

http://news.bbc.co.uk/1/hi/world/middle_east/2254712.stm. June 4, 2004.

Bush ultimatum to Saddam: Text. (2003, March 18) BBC News.

http://news.bbc.co.uk/2/hi/americas/2859269.stm. June 4, 2004.

Canada launches inquiry into Afghanistan bombing deaths. (2002, April 19) CBC News. June 3, 2004. http://www.cbc.ca/stories/2002/04/18/cdndeaths020418.

Churchill, W. (1940). Speech before Commons (June 4, 1940

http://history.hanover.edu/courses/excerpts/111chur.html. June 2, 2004.

Cohan, G. (Composer). (1917) Over there. [Song].

Death in the desert. (2004, May 25) BBC News. June 3, 2004:

http://newssearch.bbc.co.uk/cgi-bin/search/results.pl?

$\mathrm{q}=$ death + in + the + desert\&scope $=$ newsifs_av\&tab=news_av\& $=99 \& y=19$.

Donne, J. (2004) Meditation XVII. June 2, 2004.

http://www.online-literature.com/donne/409/.

Evans, G. (1991) In the national interest: A chronicle of the National Film Board of Canada from 1949 to 1989. Toronto: University of Toronto.

Garrett, M., \& King, J. (2001, November 15) US warns 'War on Terror' is just beginning. CNN.com. http://www.cnn.com/2001/US/11/14/ret.us.reax/index.html. June 4, 2004.

Henry, E. et al. (2004, May 14) GOP leaders oppose release of more abuse images. CNN.com. June 3, 2004. http://www.cnn.com/2004/ALLPOLITICS/05/12/congress.abuse/index.html.

Legg, S. (Director), and Badgley, F. (Producer). (1939) The case of Charlie Gordon. [Film].

Legg, S. (Producer \& Director). (1941) Churchill's Island. [Film].

Madrid bombing suspect tied to al-Qaeda. (2004, March 15) CBC News. June 4, 2004.

http://www.cbc.ca/stories/2004/03/14/world/Moroccan_040314.

Millions say 'no' to war in Iraq. (2003, February 16) CBC News.

http://www.cbc.ca/stories/2003/02/15/peaceactivists030215. June 3, 2004.

National Film Board of Canada. (2003) History: 1940s. Retrieved November 12, 2003 from the World Wide Web: http://www.nfb.ca/e/history/1940s.html.

Noah, T. (2004, May 26) Bin Laden, Democrat? Slate. http://slate.msn.com/id/2101319/. June 7, 2004.

Poll finds divided opinion of Bush's performance. (2004, April 9) CNN.com. June 7, 2004.

http://www.cnn.com/2004/ALLPOLITICS/04/09/bush.poll/index.html.

Rice: Terrorism fight a new kind of war. (2001, September 20) CNN.com.

http://www.cnn.com/2001/US/09/19/ret.rice.security/index.html. June 4, 2004.

'Scores killed' in US Afghan raid. (2002, July 1) BBC News.

http://news.bbc.co.uk/1/hi/world/south_asia/2079565.stm. June 3, 2004.

Shakespeare, W. (2001) Julius Caesar ®. Gill, Ed.). New York: Oxford University Press. 
Statement says al-Qaeda responsible for Kenya attacks. (2002, December 2) CBC News. June 4, 2004. http://www.cbc.ca/stories/2002/12/02/canada/alqaeda021202.

Taylor, F. (2001, September 25) Terrorist threats against America (Testimony to the Committee on International Relations). US Department of State.

http://www.state.gov/s/ct/rls/rm/2001/5215.htm. June 4, 2004.

Timeline: Steps to war. (2003, March 20) BBC News.

http://news.bbc.co.uk/1/hi/world/middle_east/2773213.stm. June 4, 2004.

UN adopts tough Iraq resolution. (2002, November 8) BBC News.

http://news.bbc.co.uk/1/hi/world/middle_east/2418975.stm. June 4, 2004.

US sub collides with Japanese fishing boat. (2001, February 11) CBC News. http://www.cbc.ca/stories/2001/02/10/world/japan_sub010210. June 3, 2004.

Video claims al-Qaeda behind suicide attacks. (2003, June 21) CBC News.

http://www.cbc.ca/stories/2003/06/21/world/qaedavideo030621. June 4, 2004.

\section{Author Information}

Robert Christopher NELLIS teaches at the Department of Secondary Education, University of Alberta, Canada. His research focuses on the National Film Board of Canada. He has written on the cultural significance of classic NFB films, including Paddle to the Sea, Paul Tomkowicz: Street-railway Switchman, and Neighbours. 